\title{
The Corporate Power of the British Monarchy: Capital(ism), Wealth and Power in Contemporary Britain
}

\section{Introduction}

Once upon a time lived a royal family headed by the elderly Queen Elizabeth II. The twenty-first century royal fairytale plays out in global media culture: heirs and spares marry princesses in spectacular displays of pomp and ceremony; royal babies are displayed to crowds of well-wishers; royal lives are documented in dramatic restagings such as The Crown (Morgan, 2016) as tales of romance and glamour. While the monarchy has remained popular in Britain for decades, central to British heritage and folklore, proroyal sentiment in Britain has recently resurged (Ipsos Mori, 2016). This is particularly due to the popularity of the younger royals, the Duke and Duchess of Cambridge ("Wills and Kate') and the Duke and Duchess of Sussex ('Harry and Meghan'), who perform(ed) an 'image of everyday normality' in a celebrity culture era (Littler, 2017: 124) as though part of an aspirational middle class (Clancy, forthcoming). Affective relationships between the royal family and 'ordinary families' are established through regular philanthropic projects, (carefully staged) media appearances, and benevolent giving (ibid.).

Simultaneously, global wealth inequalities are widening. According to development charity Oxfam (2019), globally in 2019 just 26 people owned the same wealth as the poorest 3.8 billion, and in the UK the richest 1,000 people own more wealth than the poorest 40 per cent of households (The Equality Trust, 2017). In this context, sociology has reinvigorated its interest in 'the elites' (Savage and Williams, 2008; Khan, 2014; Savage, 2015; Sayer, 2015; Smith, 2016; Atkinson et al., 2017; Davis, 2018; Friedman and Laurison, 2019), inspired particularly by Thomas Piketty's Capital in the Twenty First Century (2014), which analysed growing inequalities in relation to wealth, capital and investment.

Much of this contemporary research on 'the 1\%' (Dorling, 2014) explores transnational, meritocratic, neoliberal corporate power and the 'new rich', overlooking 'old' forms of political and institutional power in reproducing economic and cultural dis/advantage in Britain. Despite claims that landed power is in decline (Cannadine, 1990), investigative 
journalist Guy Shrubsole (2019) demonstrates that long-established and land-based wealth holding (by, for example, the Crown, the aristocracy and the church) remains central to systems of power. These 'traditional sources of wealth', as Rowland Atkinson et al. write, 'sit alongside - and increasingly interact with - the new global wealth elites and their expanding super-prime property portfolios' (2017: 184), perhaps best exemplified by aristocrats like the Duke of Westminster. Some scholarship shows how various forms of elite wealth - for example, 'the idle rich, the famous, the charitable, the titled and the industrious' (Biressi and Nunn, 2013: 119) - intersect and converge through comparable cultural, political, social and economic behaviours (Sayer, 2015; Smith, 2016; Littler, 2017; Edgerton, 2018). This research gap is perhaps partly explained by a sociological 'turn away' from earlier Marxist debates about the ruling class and economic class struggle. In so doing, Marxist frameworks like that of Silvia Federici (2004) and Ellen Meiksins Wood (1991, 1999) exploring how late capitalism remains rooted in historical forms of exploitation, extraction and class-based inequality are overlooked. Likewise, critical Marxist engagements considering the cultural political economy and historical materialism (Hall et al., 2013) are displaced.

Taking this framing as a departure point, this article considers the monarchy within wider political economies of wealth and power, in a British context increasingly shaped by inequalities and systems of dis/advantage. In public and academic commentary, the British monarchy is often positioned as an archaic institution, an anachronism in relation to corporate forms of wealth and power, and therefore irrelevant. But what happens if monarchy is placed back at the centre of class analysis?

This article emerges from a longer study on the British monarchy, which reads the political economy through culture (Clancy, forthcoming). That project analyses the cultural formations of monarchy in relation to its economic activities, to argue that media representations of the royal family are a prism; a central affective and ideological project to distance the monarchy from capitalist vulgarity and aristocratic debauchery, and reproduce monarchical power by 'producing consent' (Hall et al., 1978) for it in the public imaginary That research guides this article, but the focus here is on dismantling the symbolic royal fairytale, as described in this article's opening, to reveal the mechanics, technologies and actors 'behind the scenes', and to expose the political-economic functions of the monarchy. 
To do this, I first outline the conceptual framework by describing the monarchy as a corporation: 'The Firm'. I detail the monarchy's historical relationship with corporations and economic forms, to facilitate the unpacking of its political-economic significance today. The empirical data following this takes a classic journalistic approach of investigative research, consolidating a mass of material that was difficult to source due to the monarchy's reliance on secrecy. This material ranges from media representations (newspapers, books, documentaries, social media, blogs); statistical data (surveys); government, constitutional and legal documents; material goods (merchandise); and critical academic material on monarchy. It incorporates "official" representations produced by the monarchy, activist/republican critiques, "objective" commentary by journalists/commentators, entertainment texts, fandom materials, and public commentary on social media. I use this data to map out the key material practices of The Firm: 'Working for The Firm' (staffing, wages, job roles), 'The Economics of The Firm' (funding and wealth, economic reporting, tax payments, investments and ownership, land), and 'The Global Firm' (histories of Empire and Commonwealth). This intricate description of what monarchy is today is intended as a provocation to sociological studies of elites to suggest that, in overlooking monarchy, we are overlooking a key component of late capitalism, and a key component in the reproduction of inequalities today.

\section{The Firm: Monarchy and Corporate Power}

To understand the monarchy as part of capitalist regimes, I (re)conceptualise the monarchy as a corporation: The Firm. The Firm is a common nickname for the British monarchy with a long history seeming to originate with George VI, who is quoted as stating 'we are the Family Firm' (in Brunt, 1992: 292), referring to the royal's enactment of 'family values' during World War II (Pimlott, 2012). The term, and its shortened version 'The Firm', has since reportedly been adapted by Elizabeth II, and multiple media texts use the designation uncritically (Junor, 2006). ${ }^{1}$ This article takes the name more literally to figure the monarchy as a corporation, seeking to make visible the connections between monarchy, capital(ism), corporate power and contemporary inequalities. 
I frame the monarchy as corporation to distinguish from existing work that considers monarchy as brand (Balmer, 2009; Brand Finance Journal, 2012; Otnes and Maclaran, 2015). Contemporary marketing literature understands branding as 'distinguish[ing] a particular product or service from its competitors' (Kotler et al., 2009: 425), which means differentiating products from other (similar) items. A brand operates externally, and to examine the royal brand is, to put it bluntly, analysing what they want you to see. That is, it reproduces the frameworks the monarchy is constructing. To understand the monarchy's material practices, we must consider its historical, economic, political, social and cultural functions; functions often rendered invisible behind the symbols and spectacles of royal fairytale.

The Crown is legally a common law corporation. Medieval law used Roman ideas of the body politic as 'universitas, a corporation of the polity', to distinguish between The Crown and the monarch's natural body (Loughlin in Sunkin and Payne, 1999: 53), meaning laws made regarding, and assets belonging to, the monarch(y) will pass to the succeeding monarch (Clancy, forthcoming). Historically, The Crown used private corporations to manage public services, such as municipalities, universities or the Corporation of London, and to manage colonisation projects across the Empire (Robins, 2012). The Bubble Act 1720 decreed that chartered companies must be granted through Royal Charters - documents issued by The Crown - and many monarchs benefitted directly from trade deals through custom duties (Micklethwait and Wooldridge, 2003). The Companies Act 1862 made limited liability joint-stock companies distinct legal entities, granted the same rights as humans and negating Royal Charters (ibid.). The Industrial Revolution initiated large-scale corporations, with multidivisional organisational structures (ibid.). Finally, the period since Elizabeth II's 1953 coronation has shifted from the post-war welfare state to financial capital, neoliberal deregulation, free markets and privatisation (Harvey, 2005).

Due to their global significance and historical entrenchment in state policy, as David Ciepley has argued, 'corporations are government-like in their powers' (2013). Moreover, in the Global North corporate values are embedded in practices of everyday life (Klein, 2007). Corporate and civic citizenship increasingly intersect (Volcic and Andrejevic, 2016; Negra and McIntyre, 2019), and corporate accumulation through dispossession, exploitation and extraction expands (Skeggs, 2019). This corporate power is increasingly 
waged through capitalist dynasties such as the Bransons and the Trumps, where the family becomes 'a site of commercial productivity' (Pramaggiore and Negra, 2014: 89; see also Glucksberg and Burrows, 2016). Of course, The Firm is a family firm with a form of slavery at its core given its offspring must be royal. Framing the monarchy as a corporation is effective because corporations are organised around (im)moral modalities of exchange and logics of reciprocity, which The Firm achieves through (im/material) ideas of patronage, philanthropy, heritage and nationalism. As I demonstrate, this is perhaps clearest in journalistic calculations offsetting the monarchy's economic cost with its social 'value' to demonstrate its worth(iness). This article illustrates that often the monarchy plays the same game as corporations to sustain itself in an increasingly networked world market. Yet rather than (or, in addition to) corruption, it uses extrajuridical' forms of precedence rooted in the (uncodified) British constitution and political custom, exploiting this legal status to its advantage. In what follows, I map out what The Firm is today in order to put (histories of) capitalist formation back into conceptualisations of monarchy today.

\section{Working for The Firm}

While civil servants, military personnel and ministers could be considered monarchy employees (Wyatt in Sunkin and Payne, 1999), my narrative of domestic employment defines staff as those working in royal palaces. The Firm employs around 1,200 staff (Stockman, 2014) across the Royal Households, the largest being the Household of Elizabeth II at Buckingham Palace. This Household is overseen by the Lord Chamberlain, and work is departmentalised: the Lord Chamberlain's Office (ceremonies, public events); the Priyate Secretary's Office (constitutional and political duties, communications); The Privy Purse and Treasurer's Office (finance); The Master of the Household's Department (catering, hospitality, housekeeping); and the Royal Collection Trust (maintaining the Royal Collection) (Hoey, 2003; Burrell, 2004). This personnel organisation reflects bureaucratic multidivisional corporations, with the Queen the equivalent to Vice President, the Lord Chamberlain as Chairman, the Queen's Private Secretary as Managing Director/Chief Executive, and Heads of Department as sector managers.

Accounts from inside the Household suggest a strictly demarcated staff hierarchy usually built around proximity to the royals (Barry, 1983) and policed by a dramaturgy of ritual 
and etiquette. They have segregated dining locations/timings, whereby 'junior members' (butlers, housekeepers) eat self-service meals using plastic seats and plastic cutlery; 'officials' (long-serving staff, dressers, chauffeurs) dine on upholstered chairs with silver cutlery; 'senior officials' (personal secretaries, press officers) are permitted sherry or wine, and 'members' (ladies-in-waiting, Private Secretary) are served by junior staff (Burrell, 2004). There are inconsistent hiring practices and enormous variations in wages and benefits. While senior staff are typically headhunted and often employed without formal interview (Somerset, 1984; Hoey, 2003; Arbiter, 2014), lower-level staff must complete an application form, undertake an interview, and sometimes attend an Assessment/Day (Brookes, 2015). A Housekeeping Assistant position was advertised in 2015 at $£ 14,513.16$ per annum (The Royal Household, 2015), which, presuming a 37.5 hours per week contract (it advertises for 'five days'), is barely more than the 2015 London living wage of $£ 9.40$ per hour. ${ }^{2}$ Pay scales for senior staff are not advertised, but biographer Brian Hoey (2011) suggested that in 2011 the Queen's Private Secretary was paid $£ 146,000$ and the Keeper of the Privy Purse $£, 180,000$. In 2011-12, pay was frozen for staff earning over $£ 21,000$ (National Audit Office, 2013), but reports suggested some of the top earners saw increases of up to 6.4 per cent regardless (Press Association, 2013; McClure, 2014). This reflects how UK elite wages continue to rise after the North Atlantic financial crash and austerity economics, despite average UK household income decreasing (Elliott, 2017). Meanwhile, reflecting the global 'gig economy' model, temporary contracts are used across Royal Households. Some cleaners are agency staff (Shakespeare, 2015); footmen are sourced from elite colleges for unpaid "internships" at state banquets (Hoey, 2003); and 350 part-time summer staff worked on zero-hour contracts for Buckingham Palace's summer opening in 2013 (Neville et al., 2013).

White male employees dominate. The government's 2018 gender pay gap report showed that women in the Royal Household are paid 12.39 per cent less than men (Palmer, 2018), and the first black equerry was only hired in 2017 (Pells, 2017). Although the official Royal website includes a 'diversity and inclusion' policy stating they 'raise awareness of diversity and equal opportunities throughout our workforce', and hire purely on merit (Official Website of the British Monarchy, 2016) it does not detail how this occurs (indeed, the gender pay gap suggests it is ineffective). Statistics on racial diversity within the Royal Household are not available. In 1997, The Independent revealed that statutory policies on ethnic monitoring of staff, used across the UK for decades, was 
not being used by The Firm (Bevins, 1997). In response, they claimed 'the number of current employees from an ethnic minority background is about 5 per cent... in line with ethnic minority representation across the civil service' (ibid.). The civil service figure was actually 18.4 per cent in Greater London, and The Firm undertook no ethnic monitoring of current staff by position, making it impossible to calculate whether BAME employees were fairly distributed across pay grades (ibid.). In 2001 Elizabeth Burgess, a black woman and former personal assistant to Prince Charles, went to tribunal over discrimination and racist bullying by other staff (Pells, 2017). Her claims were dismissed.

In addition to underpaid, under-rewarded 'domestic' staff, over-representation from elite schools, landowners and titled families suggest accumulations of class privilege in senior members. For example the Lord Chamberlain William James Robert Peel is a House of Lords peer (The Peerage, 2015), and ex-Private Secretary Sir Christopher Geidt owns a 365-acre sheep farm (Kerevan, 2015). There are also cross-institutional relationships, with three key previous and/or future employers among senior staff: corporations, broadcasters and the civil service. This 'revolving door' (Davis, 2018: 126) between Establishment networks is typical of elite institutions to preserve privilege and wealth. Keeper of the Privy Purse Sir Alan Reid and his deputy Michael Stevens have both worked for finance corporation KPMG (The Telegraph, 2011). The Private Secretary Edward Young was previously Deputy Head of Corporate Public Relations at Barclays Bank (Pascoe-Watson, 2012), and the Duke and Duchess of Cambridge's Communication Secretary, Jason Knauf, was Director of Corporate Affairs at RBS (Rayner, 2014a). This reveals how corporate businessmen appeal to Royal Household strategies, demonstrating the merging of 'new' and 'old' money.

Several senior Household members have worked for key inter/national broadcasters: Edward Young was Head of Communications at Granada (Pascoe-Watson, 2012), and Sally Osman (ex-Director of Royal Communications) was Director of Corporate Communications for Sony, Director of Communications for BBC, and Director of Press and PR for Channel 5 and British Sky Broadcasting (Rayner, 2013). This suggests The Firm has access to broadcast institutions through interdependent relationships, and that The Firm's communications team have a skill in packaging royal events in digestible ways for the news cycle. 
Just as early modern courts were populated by aristocrats and noblemen at the centre of government and society (Elias, 1983), The Firm's court includes influential figures. Sally Osman, James Roscoe (ex-Communications Secretary to the Queen) and Jason Knauf were listed in the Evening Standard's 'Progress 1000: London's most influential people 2017' in the 'Communicators: Media' category (Evening Standard, 2017). Meanwhile, the Private Secretary is part of a 'golden triangle' of senior royal courtiers and civil servants, alongside the Cabinet Secretary and the Prime Minister's Private Secretary (Watt, 2014). The Private Secretary (who has always been male) communicates between the monarch and government (Bogdanor, 1995), coordinates official correspondence, and organises the monarch's programme (including writing speeches). Paul H. Emden suggests 'to prescribe the limits of his activities, to fix once and for all the sphere of his influence, is impossible' (1934: 14). Despite its importance, the position evolved organically and is neither elected nor well known (Bogdanor, 1995).

Some roles are always filled by aristocrats, such as Ladies-in-Waiting (Hoey, 2003). These positions are not advertised but rely on personal contacts, and Ladies-in-Waiting are unpaid (aside from travel expenses) and work in a two-weeks-on-four-weeks-off pattern (Somerset, 1984). With no pay, the role functions as a mark of honour (The Royal Post, 2013), and as an aristocratic classed dedication to the reproduction of royal power. It is also an example of unpaid gendered domestic labour.

Questions are raised about staff's investment in reproducing The Firm when they experience poor wages and living conditions. Stephen Barry, Prince Charles's valet, said many staff 'are natural royalists who work for the monarchy for the same romantic reasons I did (1985: 20), and motivations pivot on moral economies of class subservience. Even senior household members are paid less than in comparable corporate institutions, suggesting that the networks, privileges and status the Royal Household affords is important across the employment divide. The workforce is essentially bifurcated with, on the one hand, low- to middle-income 'domestic workers' who do the essential, daily, unglamorous work of maintaining The Firm, and then a symbolically and politically important group of senior and honorary staff who are linked into broader British elites and have 'real' social, cultural and political power. Either way, all are key to reproducing The Firm as a national institution and in reproducing corporate power across the 'revolving door' (Davis, 2018: 126) of the elites. 


\section{The Economics of The Firm}

The British government has provided funds to the monarch since 1688 (Tomkins in Sunkin and Payne, 1999). A fixed payment developed to give parliament more control over expenditure, where previously it fluctuated with each monarch's whims (ibid.). Between 1760-2011, this was the Civil List: an annual payment, rising with inflation, in return for the Crown Estate profits, a portfolio of land and property belonging to The Crown (National Audit Office, 2013). The last Civil List payment in March 2011 was f7.9 million (ibid.). This was supplemented by grants-in-aid, which funded official engagements, travel (including helicopter, chartered flights and the royal train), and property maintenance (ibid.). In 2015, royal travel cost $£ 4$ million (Herald Scotland, 2016). Crucially, only the Queen claimed from the Civil List. The Dukes and Duchesses of Cornwall, Cambridge and Sussex are financed by profits from the Duchy of Cornwall, and other members receive income from the Privy Purse (Brand Finance Journal, 2012). The Privy Purse comprises surplus income from the Duchy of Lancaster, another portfolio of Crown land and property, which totaled $£ 20$ million in 2017 (Prynn, 2017; the Duchy is valued at $£, 534$ million). Funding was completed by the Queen's 'personal income' from her 'private' investment portfolio (including the Balmoral and Sandringham Estates; ibid.). The concept of 'personal wealth' is questionable considering the monarchy's history of extraction, enclosure and exploitation (Clancy, forthcoming).

In October 2011, the Civil List and grants-in-aid were replaced with the Sovereign Grant (the Duchy of Cornwall, the Privy Purse and 'personal' funding remain). This restructure aimed to improve accountability, and the annual payment is now calculated from a percentage of the Crown Estate's net income, with the National Audit Office and Public Accounts Committee undertaking regular examinations (National Audit Office, 2013). However, as anti-monarchy campaigners Republic report (2015), concerns arising from these examinations are routinely dismissed by the government. Furthermore, although the Financial Times used financial capitalist language to describe the Sovereign Grant as 'performance-related pay' (Shrimsley, 2011), and this was the aim of the restructure, the payment does not reflect actual profits/losses of the Crown Estate. A House of Commons Research Paper stated this was merely 'a means of arriving at a figure' (Bowers and Cracknell, 2011). This lack of accountability is reflected in recent payment increases. In 2011, The Firm received 15 per cent of the Crown Estate's net income 
surplus (National Audit Office, 2013), but in 2017 the Royal Trustees (the Prime Minister, the Chancellor of the Exchequer and the Keeper of the Privy Purse) agreed to 25 per cent, plus an additional 10 per cent annually to fund the 10-year 'Reservicing of Buckingham Palace' project. This amounted to $f^{8} 82.2$ million in 2018-19 (The Royal Household of Queen Elizabeth II, 2019), up from $£_{4} 40$ million in 2014-15 (Republic, 2015). As David McClure puts it, paraphrasing the Financial Times, this bears 'a remarkable resemblance to the generous performance-related pay packages granted to business executives by their indulgent boards' (2014: 422).

Since 1993, The Firm has published annual finance reports purporting to encourage financial accountability (for example, The Royal Household of Queen Elizabeth II, 2019). However, figures are routinely obscured. For the Sovereign Grant increase described above, the 2017-18 report first highlighted a 'core' Sovereign Grant of $£ 445.7$ million, with the additions in the subsequent paragraph (The Royal Household of Queen Elizabeth II, 2018). Likewise, the Queen's report only includes Sovereign Grant income, ignoring other operational costs 'cross-subsidis[ed]' by government departments (McClure, 2014: 419). The Department for Culture, Media and Sport fund ceremonials; the Foreign and Commonwealth Office fund state visits; the Ministry of Defence pays equerries and orderlies wages; the Home Office provides security and police support; (National Audit Office, 2013); and the Queen's country estates receive European Union farming subsidies of over $f 1$ million (Brexit will likely end this agreement; Riley-Smith, 2016; Moore, 2016). Journalists also uncovered that The Firm attempted to claim funds to heat Buckingham Palace under an energy-saving scheme designed for low-income families (Verkaik, 2010a). A Sovereign Grant clause states funding can never decrease even if Crown Estate profits do, but can increase when profits go up (Republic, 2015; especially pertinent given the austerity cuts to public instititions like the NHS), reflecting a more pervasive neoliberal practice which socialises losses and privatises profits. Discourses of accountability, then, seem merely to assuage public opinion around elite privilege (Littler, 2017), and reflect the corporate accounting of global companies like Amazon which 'manipulate results' to appeal to shareholders (Sherman and Young, 2016).

By law, The Crown is exempt from taxation, and the Sovereign Grant is exempt from income tax (HM Government, 2013). In 1993, responding to public anger over royal 
spending, The Firm agreed to pay 'voluntary' income and capital gains tax on the Privy Purse and private investments, but only 'to the extent that the income is not used for official purposes' (The Royal Household of Queen Elizabeth II, 2019: 7). The Crown is also exempt from inheritance tax on 'sovereign to sovereign bequests' (Marr, 2011: 295). The Queen does pay council tax on her properties: $f_{1.4}$ million in 2018 (The Royal Household of Queen Elizabeth II, 2019). In 2017, leaked documents from two offshore tax havens in the Cayman Islands revealed that the Duchy of Lancaster had followed multiple global corporations to use offshore private equity funds to avoid paying tax on its holdings (Osborne, 2017). These investments had been put into multiple businesses, including BrightHouse, Britain's largest rent-to-own retailer 'criticised for exploiting thousands of poor families' (ibid.) by charging huge interest rates on purchases using cost credit. Despite controversy, The Firm has never publically apologised (Clancy, forthcoming).

Due to skewed and/or omitted figures, The Firm's wealth is equally difficult to calculate. This is perhaps attributable to misunderstood differences between the Queen's 'personal investments' and property of The Crown. The Queen's 'personal investments' are assets legally hers to maintain, use or sell (Marr, 2011), including the Balmoral and Sandringham estates, 'personal possessions', and 'personal investment portfolios' held by blue-chip subsidiary Bank of England Nominees - a dormant company exempt from disclosing its accounts (Bates, 2015). Properties of The Crown, meanwhile, are held in trust for the nation by the Sovereign, passing to the new Sovereign upon succession. These include the Crown Estate, the Duchy of Lancaster, Royal Collection artwork ${ }^{3}$, most palaces and castles, jewellery (including the Crown Jewels), and land. Because the Queen is not entitled to these profits, they are often omitted from 'official' calculations, although Republic (2015) argue that citizens lose profits accruing from them.

The Crown Estate is a portfolio of land and property belonging to The Crown, while the Duchy of Lancaster is owned by the sovereign as the Duke of Lancaster, and the Duchy of Cornwall by the Duke of Cornwall, currently Prince Charles (see Clancy, forthcoming for an analysis of the latter). The Crown Estate incorporates UK residential and commercial property, including the entirety of London's Regent Street, most of St James's Park, some of Regent's Park, Kensington Palace Gardens, Eltham, Richmond, Egham and Hampton; three shopping centres; fourteen retail parks; most of the UK's 
seabed and foreshore including wind, wave and tidal power, marine aggregates and minerals, cables and pipelines; and 336,000 acres of agricultural land and forestry (The Crown Estate, 2016a). In 2018, it announced a capital value of $£ 14.1$ billion (The Crown Estate, 2018). It is described as an 'independent commercial business' (The Crown Estate, 2016b) separate from monarchy but run on its behalf. However, much of its portfolio was 'stolen from the Church at the time of the Reformation' or conquered by historical monarchs (Duncan, 1970: 194). In 2019, The Guardian (Murphy, 2019) revealed that over five years 113 Crown Estate tenants were evicted so the homes could be sold for profit, and over 100 complaints from tenants (about leaks, faulty electrics, etc.) were received in two years, prompting questions about the management's morality considering the Crown Estate is a custodian rather than a commercial estate agent. As described earlier, landed wealth remains central to systems of power in Britain, across both the persistence of the aristocracy and corporations investing in land for financialisation (Shrubsole, 2019). Likewise, Brett Christophers (2019) and Beverley Skeggs (2019) argue that late capitalism has turned (back) to capitalist formations based on rent, expropriation, enclosure and exploitation to extract profit and value. Failures in land reform, described by Michael Tichelar (2018), also contribute towards understanding the resilience of the landed classes. This demonstrates further interrelations between the economic models of monarchy and corporate, financial capitalism (see Clancy, forthcoming for more on The Firm and land).

When laid bare, these figures are staggering. However, royal funding and/or wealth is offset in public discourse against notions of their wider cultural, historical or economic 'value' to British society. Headlines such as 'Thank you Ma'am: Royals earn Britain nearly £2billion a year' (Palmer, 2017), 'The Queen costs her subjects 60p each a year' (Davies, 2003) and 'Monarchy attracts $f, 500$ million a year from overseas tourists' (Gammell, 2010) use mathematical calculations to appeal to capitalist logics of 'value for money' and exchange. ${ }^{4}$ Likewise, The Firm's initiatives suggest the production and distribution of broader economic value, such as endorsing goods, practices, or places - the honours system, for example, (see Harper, 2015) - or philanthropic/patronage projects described as 'royal work' to position the royals as productive forces in a labour market (see Clancy, forthcoming). Of course, as I demonstrate, this is not a process of exchange among equals at all. Rather, like David Graeber argues (2013) of broader economic histories, while economic relations are embedded in ideologies of morality - for instance, debt 
repayment as a moral imperative - in fact hierarchies order moral relations of inequality, conducted as logics of precedence and privilege. Indeed, the legal bases for monarchical privileges are entrenched in past actions informing present propriety, whilst affective investments in the royal family-across both public and media cultures - offset the cost of monarchy against moral economies. Hence, historical relations of monarchical wealth accumulation are obscured.

This account has exposed where monarchical funding comes from, how it gets concealed, and how The Firm exploits ancient prerogatives to reproduce wealth in late capitalist Britain. As Ellen Meiksin Wood argues, Britain has 'a kind of 'bastard capitalism' with a pre-modern state and antiquated ruling ideologies' (1991:1) that affect the entire system, structuring relations between 'new' and 'old' elites.

\section{The Global Firm}

Contemporary financial capitalism is a transnational project (Sassen, 2001)., Marxist feminist and black Marxist work describes capitalism's dependency on population subjugation through exploitation, extraction, conquest, displacement and slavery (Williams, 1964; Federici, 2004; Lowe, 2015). For example, corporations undertook colonisation projects across the British Empire, run on behalf of the British State and the monarch. The East India Company was granted a Royal Charter in 1600, and used its private army to rule millions and establish monopolies over global trade (Robins, 2012). The British Empire implemented violent regimes of genocide, famine, enslavement, indentured labour, imprisonment and torture, all presided over (and partly funded) by the monarch(y) (Beckles, 2012). Likewise, The Firm continues to use, and extract value from, goods stolen during colonisation, such as the Koh-i-Noor diamond from India used in the crown jewels (Dalrymple, 2017). Analysing The Firm's global interests reveals how The Firm reshapes itself in response to changes in capital and global governance, moving from the household to the globe.

The Commonwealth is a transnational organisation of 52 'independent and equal' member states headed by the Queen, promoting principles of peace and security, human rights, tolerance, and access to health, education, food and shelter through the Commonwealth Charter (The Commonwealth, 2013). These 'shared values' have proved contentious. Philip Murphy describes the Charter as 'so poorly drafted that it leaves the 
nature of [the nations'] commitment [to particular values] completely unclear' (2018: 156). This is illustrated in some member states' human rights records, such as criminalising homosexuality despite the Charter's 'discrimination clause' (ibid.). The Commonwealth also has imperial origins. Many member states are former British colonies, and Murphy describes the 'haphazard' way "Imperial' became 'Commonwealth” (2018: 43). Holly Randell-Moon argues 'the secular autonomy of settler states is buttressed by Crown sovereignty' (2016: 41) with regular royal visits to promote ties. The enshrining of neocolonialism through organised alliances is notable considering how contemporary authoritarian populist politics draws on affective, colonial nostalgia (Virdee and McGeever, 2017; Yelin and Clancy, forthcoming). The Firm functions in this nostalgia as representative of 'traditional', conservative, specifically English national identity (Clancy, forthcoming) that must be 'protected'. For example, as I explore elsewhere (ibid.), the misogynistic, racist comments about Meghan Markle's marriage into The Firm, which draw on white supremacist discourses that position interracial marriage as tarnishing (royal) blood purity, demonstrate how (nostalgia about) royal whiteness can be mobilised to spread far-right populist propaganda.

While the London Declaration 1949 permitted Commonwealth countries - as 'free and equal members' - to adopt republicanism, sixteen remain constitutional monarchies with Elizabeth II as a legally distinct Head of State (Ritchie and Markwell, 2006). These include Caribbean islands like Barbados, African states such as Ghana, and Australia and Canada (Estep, 1993). Canada was unified in 1867 and Australia in 1901, when each developed independent constitutions as self-governing dominions, while vesting 'executive power' in the British Crown (Estep, 1993: 225). They nominate a local governor-general as the Queen's representative, with the power to propose legislation, (dis)prove bills and dissolve parliament (Boyce, 2008). Although the Queen has no 'direct' political control in these realms, governor-generals can be interpreted as ongoing monarchical administrative power. Likewise, as Caribbean sociologist Ty Salandy writes, the British Empire was partly consolidated by 'the violence of 'knowledge'... spreading a narrow and ideological system of values, culture and information' to form a 'global model of civilization' (Salandy, 2018). Adopting 'God Save the Queen/King' as the national or royal anthem, for example (still used in Australia, Jamaica, Grenada, Saint Lucia, Tuvalu and Barbados, amongst others), instills British values and subservience to colonial authority by evoking monarch(y). Additionally, intergovernmental agency The 
Commonwealth Secretariat runs the Commonwealth, describing itself as a 'civil society': 'a body accountable to "the people" of the Commonwealth' (Murphy, 2018: 51). Yet, it relies on a 'corporatist model' where “civil society' consultations' are dominated by corporate groups (ibid.), such as the Commonwealth Enterprise and Investment Council which promotes intra-Commonwealth trade and investment between government and private sectors (CWEIC, 2017).

The Firm has further interests in international trade. Prince Andrew 'worked' for the UK government in the Department for Business, Innovation and Skills as the Special Representative for International Trade and Investment. This ended in 2011, following reports that Andrew profited personally from trade deals. He allegedly exploited his personal relationship with Kazakh oligarch Kenges Rakishev to broker a f885 million deal between a Greek and Swiss consortium and the Kazakhstan government, receiving $£ 4$ million commission (Telegraph Reporters, 2016). In 2007, he sold his Berkshire country estate Sunninghill Park to Kazakh oligarch Timur Kulibayev for $£ 3$ million above the asking price, and in 2011 he allegedly lobbied British bank and wealth manager Coutts to accept Kulibayev as a client (ibid.). Ex-Foreign Office Minister Chris Bryant claimed 'it was very difficult to see in whose interésts [Andrew] was acting' (Sawer, 2016). Likewise, some royal visits to places like Saudi Arabia have coincided with arms trade sales by BAE systems, suggesting the royals are used to broker corporate sales (Margrain, 2017). The Firm's global interests demonstrate how it follows finance capital models, operating across borders to (re)produce wealth and power.

\section{Conclusion}

This article aimed to trouble typical accounts of the British monarchy as an archaic institution, an anachronism in relation to corporate forms of wealth and power, and therefore irrelevant. To do this, it conceptualised the monarchy as a corporation: The Firm. The article mapped what monarchy is today to expose its corporate interests: from exploiting low-paid workers; the 'revolving door' (Davis, 2018: 126) between the Royal Household and other institutions; ambiguous royal finances; networks of contacts; abusing neo/colonialism; and misusing political privileges.

It also described the moral economies (Graeber, 2013) that accompany political economies of monarchy. On one hand, The Firm is wealth 'made visible' as institutional 
and ceremonial classed power. Concomitantly, the sources, mechanisms and processes of this wealth are rendered invisible and inscrutable. I describe elsewhere (Clancy, 2019: 442) how this balance of in/visibility is a 'point of anxiety' of The Firm, not solely through 'branding' but through various material sets of organisation. In this article, visibility is controlled to avoid scrutiny, and is partly achieved through moral economies which conceptualise The Firm as 'value (for money)', or exploit workers through notions of class subservience. It is notable that the relations described in this piece are not commonly known. It is this balance of in/visibility that facilitates our affective investments in monarchy, and influences our moral attitudes to extreme inequalities. Only when romanticised representations of monarchy are fractured - as recently with Prince Andrew's role in convicted pedophile Jeffrey Epstein's sex trafficking of young girls, or Prince Harry and Meghan Markle's resignation from royal life- are the corruptions and inequalities in The Firm made temporarily visible (Clancy and Yelin, forthcoming). Indeed, Harry and Meghan's departure - which occurred after the completion of this article - indicates perhaps the most seismic shift in The Firm in recent decades, with the repercussions still playing out across media and political culture.

This argument is not only relevant to Britain. As I have shown in relation to histories of Empire and the Commonwealth, the international relevancy of The Firm indicates its global political-ideological significance in terms of reproducing inequalities and privilege: normalising elite wealth (Littler, 2017; Clancy, forthcoming) and shoring up racial capitalist structures and (neo)colonial exploitation both economically (goods stolen during Empire) and culturally (patronage visits to Commonwealth nations). Likewise, this research contributes to literature considering other global monarchies and their role in contemporary capitalist structures (Hanieh, 2018) or the persistence of 'old' wealth in capitalist accumulation (Shrubsole, 2019).

The article has demonstrated the importance of including monarchy in analyses of class and inequality. While 'elite' research has increased in response to growing global inequalities, that work largely overlooks hereditary and 'old' wealth, or Marxist conceptualisations of 'the ruling class'. How does the economic form of wealth (financial capital) play out in social forms of inequality in Britain today? How do 'new' forms of capital support and legitimate 'older' forms of power? This article details why a critical 
sociology of monarchy is so timely: how can we understand social inequalities today while overlooking a key institution of class power?

\section{References}

Arbiter, D. (2014) On Duty With The Queen: My Time as a Buckingham Palace Press Secretary. Surrey, UK: Blink Publishing.

Atkinson, R., Parker, S. and Burrows, R. (2017) 'Elite Formation, Power and Space in Contemporary London.' Theory, Culture and Society pp. 1-22.

Balmer, J. M. (2009) 'Scrutinising the British Monarchy: The corporate brand that was shaken, stirred and survived.' Management Decision, 47(4) pp. 639-675.

Barry, S. P. (1983) Royal Service: My Twelve Years as Valet to Prince Charles. New York, USA: Macmillan Publishing Co.

Barry, S. P. (1985) Royal Secrets: The View From Downstairs. New York, USA: Villard Books.

Bates, S. (2015) Royalty Inc.: Britain's Best Known Brand. London: Aurum Press Ltd.

Beckles, H. McD. (2012) Britain's Black Debt: Reparations for Caribbean Slavery and Native Genocide. Jamaica: University of the West Indies Press.

Bevins, A. (1997) The Queen fails in duty to minorities. The Independent. [Accessed 18/08/2016] http://www.independent.co.uk/news/the-queen-failsin-duty-to-minorities-1249486.html.

Biressi, A. and Nunn, H. (2013) Class and contemporary British culture. Basingstoke: Palgrave Macmillan.

Bogdanor, V. (1995) The Monarchy and the Constitution. Oxford: Oxford University Press.

Bowers, P. and Cracknell, R. (2011) Sovereign Grant Bill. London: House of Commons.

Boyce, P. J. (2008) The Queen's Other Realms: The Crown and Its Legacy in Australia, Canada and New Zealand. Sydney, Australia: The Federation Press.

Brand Finance Journal (2012) Understanding the Value of the British Monarchy as a brand. Brand Finance.

British Monarchy (2016) Inside the Royal Household. Official Website of the British Monarchy. [Accessed 24/10/2016] https://www.royal.uk/inside-theroyal-household. 
Brookes, J. (2015) 'Upstairs and Downstairs: A Job Interview at Buckingham Palace.' Royal Central. 6th January. [Accessed 23/09/2016]

http://royalcentral.co.uk/blogs/upstairs-and-downstairs-a-job-interview-atbuckingham-palace-42653.

Burrell, P. (2004) A Royal Duty. London: Penguin.

Cannadine, D. (1990) The Decline and Fall of the British Aristocracy. New Haven and London: Yale University Press.

Christophers, B. (2019) 'The rentierization of the United Kingdom economy:' Environment and Planning A: Economy and Space, September.

Ciepley, D. (2013) 'Beyond Public and Private: Toward a Political Theory of the Corporation.' American Political Science Review, 107(1) pp.139-158.

Clancy, L (2019). "Queen's Day, TV's Day': The British Monarchy and the Media Industries'. Contemporary British History, 33(3), pp.427-450

Clancy, L (forthcoming). Why Monarchy Matters: The Cultural Politics of the British Royal Family. Manchester, UK: Manchester University Press

Clancy, L and H Yelin (forthcoming). 'Monarchy is a Feminist Issue: Andrew, Meghan and the \#MeToo Era Monarchy'. Women's Studies International Forum

Commonwealth Network (2017) 'International NGOs.' Commonwealth of Nations. [Accessed 10/02/2017]

http://www.commonwealthofnations.org/sectors/civil_society/international_ng os/.

CWEIC (2017) About CWEIC. CWEIC. [Accessed 15/02/2017] http://www.cweic.org/about/.

Dalrymple, W. (2017) Koh-i-Noor: The History of the World's Most Infamous Diamond. London: Bloomsbury Publishing.

Davies, C. (2003) The Queen costs her subjects 60p each a year - Telegraph. The Telegraph. [Accessed 31/10/2019]

https://www.telegraph.co.uk/news/uknews/1434183/The-Queen-costs-hersubjects-60p-each-a-year.html.

Davis, A. (2018) Reckless Opportunists: Elites at the end of the Establishment. Manchester: Manchester University Press.

Dirks, N. B. (2008) The Scandal of Empire: India and the Creation of Imperial Britain. Cambridge, MA: Harvard University Press.

Dorling, D. (2014) Inequality and the 1\%. London: Verso.

Duncan, A. (1970) The Reality of Monarchy. London: Pan Books Ltd. 
Edgerton, D. (2018) The Rise and Fall of the British Nation: A Twentieth-Century History. London: Allen Lane.

Elias, N. (1983) The Court Society. New York, USA: Pantheon Books.

Elliott, L. (2017) 'Household income falling at fastest rate since 1976 as UK savings rates crash.' The Guardian. 30th June. [Accessed 7/12/2018] https://www.theguardian.com/business/2017/jun/30/britons-savings-atrecord-low-as-household-incomes-drop-says-ons.

Emden, P. H. (1934) Behind the Throne. London: Hodder and Stoughton.

Estep, D. (1993) 'Losing Jewels from the Crown: Considering the Future of the Monarchy in Australia and Canada.' Temple International and Comparative Law Journal, 7(2) pp.217-242.

Evening Standard (2017) Progress 1000: Media. Evening Standard. [Accessed 13/08/2018] https://www.standard.co.uk/news/the1000/progress-1000londons-most-influential-people-2017-communicators-media-a3656386.html.

Federici, S. (2004) Caliban and the Witch: Women, The Body, and Primitive Accumulation. New York, USA: Autonomedia.

Friedman, S. and Laurison, D. (2019) The Class Ceiling. Bristol, UK: Policy Press.

Gammell, C. (2010) 'Monarchy attracts $£ 500$ million a year from overseas tourists.' The Telegraph. 28th July. [Accessed 24/05/2015]

http://www.telegraph.co.uk/news/uknews/7914479/Monarchy-attracts-500million-a-year-from-overseas-tourists.html.

Glucksberg, L. and Burrows, R. (2016) 'Family Offices and the Contemporary Infrastructures of Dynastic Wealth.' Sociologica, 2 pp. 1-23.

Graeber, D. (2013) Debt: The First 5,000 Years. New York: Melville House Publishing.

Hall, S., Critcher, C., Jefferson, T., Clarke, J. and Roberts, B. (2013) Policing the crisis : mugging, the state, and law and order. 2nd ed., London: Macmillan.

Hanieh, A. (2018) Money, Markets and Monarchy. Cambridge, UK: Cambridge University Press.

Harper, T. (2015) 'Voluntary Service and State Honours in Twentieth-Century Britain.' The Historical Journal, 58(2) pp. 641-661.

Harvey, D. (2005) A brief history of neoliberalism. Oxford: Oxford University Press.

Herald Scotland (2016) Royal train trip from Scotland to Yorkshire cost taxpayers £33,000. HeraldScotland. [Accessed 16/11/2016] 
http://www.heraldscotland.com/news/14584113.Royal_train_trip_from_Scotlan d_to_Yorkshire_cost_taxpayers_33_000/.

HM Government (2013) Memorandum of Understanding on Royal Taxation. London: House of Commons.

Hoey, B. (2003) At Home with the Queen. London: Harper Collins.

Hoey, B. (2011) Not in Front of the Corgis: Secrets of Life Behind the Royal Curtains. London: The Robson Press.

Junor, P. (2006) The Firm: The Troubled Life of the House of Windsor. London: Harper Collins.

Kerevan, G. (2015) A mere royal messenger, or a key political player? The National. [Accessed 26/08/2016] http://www.thenational.scot/comment/amere-royal-messenger-or-a-key-political-player.1294.

Khan, S. R. (2014) 'Understanding Elites.' Manchester University.

Klein, N. (2007) The Shock Doctrine. London: Penguin,

Kotler, P., Lane Keller, K., Brady, M., Goodman, M. and Hansen, T. (2009) Marketing Management. Essex: Pearson Education Ltd.

Littler, J. (2017) Against Meritocracy: Culture, power and myths of mobility. London: Routledge.

Lowe, L. (2015) The Intimacies of Four Continents. Durham, NC: Duke University Press.

Margrain, D. (2017) The Royal Family: making a killing from the arms trade. Scisco Media. [Accessed 11/07/2018] https://sciscomedia.co.uk/royal-familymaking-killing/.

Marr, A. (2011) The Diamond Queen: Elizabeth II and Her People. London: MacMillan.

McClure, D. (2014) Royal Legacy: How the royal family have made, spent and passed on their wealth. London: Thistle Publishing.

Meiksins Wood, E. (1991) The Pristine Culture of Capitalism. London: Verso.

Meiksins Wood, E. (1999) The Origin of Capitalism. London: Monthly Review Press.

Micklethwait, J. and Wooldridge, A. (2003) The Company: A Short History of a Revolutionary Idea. London: Weidenfeld \& Nicolson.

Moore, F. (2016) Brussels to strip Queen of £1million funding amid 'Hard Brexit' row. Express. [Accessed 27/03/2017]

http://www.express.co.uk/pictures/galleries/8617/EU-Leaders-meet-to- 
discuss-migration-trade-and-Russia-Brexit-Angela-Merkel-Theresa-May-galleryin-pictures.

Morgan, P. (2016) 'The Crown.' UK: Netflix.

Murphy, P. (2018) The Empire's New Clothes: The Myth of the Commonwealth. London: C Hurst \& Co Publishers Ltd.

Murphy, S. (2019) 'Crown estate faces tenants' anger over rent hikes, evictions and repair delays.' The Guardian. 30th June. [Accessed 1/07/2019] https://www.theguardian.com/society/2019/jun/30/crown-estate-facestenants-anger-over-rent-hikes-evictions-and-repair-delays.

National Audit Office (2013) The Royal Household: The Sovereign Grant. London: House of Commons.

Negra, D. and McIntyre, A. P. (2019) 'Ireland Inc.: The corporatization of affective life in post-Celtic Tiger Ireland.' International Journal of Cultural Studies.

Neville, S., Taylor, M. and Inman, P. (2013) 'Buckingham Palace uses zero-hours contracts for summer staff.' The Guardian. 30th July. [Accessed 07/03/2016] http://www.theguardian.com/money/2013/jul/30/buckingham-palace-zerohours-contracts.

Official Website of the British Monarchy (2016) Diversity and inclusion. The Royal Family. [Accessed 08/01/2020] https://www.royal.uk/diversity-andinclusion-0.

Osborne, H. (2017) 'Revealed: Queen's private estate invested millions of pounds offshore.' The Guardian. 5th November. [Accessed 06/11/2017] http://www.theguardian.com/news/2017/nov/05/revealed-queen-privateestate-invested-offshore-paradise-papers.

Otnes, C. C. and Maclaran, P. (2015) Royal Fever: The British Monarchy in Consumer Culture. California, USA: University of California Press.

Oxfam (2019) 5 shocking facts about extreme inequality. 04 October. [Accessed 08/01/2020] https://www.oxfam.org/en/5-shocking-facts-about-extremeglobal-inequality-and-how-even-it

Palmer, R. (2017) Thank you Ma'am: Royals earn Britain nearly E2billion a year. Express.co.uk. [Accessed 31/10/2019]

https://www.express.co.uk/news/uk/881710/Royal-Family-monarchy-QueenPrince-Philip-Prince-William-Prince-Harry.

Palmer, R. (2018) 'Gender pay gap row: Buckingham Palace's female staff paid 12\% LESS than men.' Daily Express. 29th March. [Accessed 11/07/2018] https://www.express.co.uk/news/royal/939107/Buckingham-Palace-genderpay-gap-Queen-Elizabeth-female-staff-paid-less. 
Pascoe-Watson, G. (2012) 'Queen of the spinners.' New Statesman. 30th May. [Accessed 24/10/2016]

http://www.newstatesman.com/politics/politics/2012/05/queen-spinners.

Pells, R. (2017) The Queen has hired her first ever black assistant. The Independent. [Accessed on 14/08/2017]

http://www.independent.co.uk/news/people/queen-elizabeth-hires-first-everblack-assistant-royal-major-nana-kofi-twunmasi-ankrah-a7831596.html.

Piketty, T. (2014) Capital in the Twenty-First Century. Massachusetts, USA: Harvard University Press.

Pimlott, B. (2012) The Queen: Elizabeth II and the Monarchy. 2nd ed., London: Harper Press.

Pramaggiore, M. and Negra, D. (2014) 'Keeping Up with the Aspirations: Commercial Family Values and the Kardashian Family Brand.' In Reality Gendervision: Sexuality and Gender on Transatlantic Reality Television. Durham, NC: Duke University Press, pp.76-96.

Press Association (2013) Royal household slated on top pay. AOL Money UK. [Accessed on 07/10/2016] money.aol.co.uk/2013/10/15/royal-householdslated-on-top-pay/.

Prynn, J. (2017) Queen's private income from Duchy of Lancaster estate hits £20m. Evening Standard. [Accessed on 04/07/2019] https://www.standard.co.uk/news/uk/queens-private-income-from-duchy-oflancaster-estate-hits-20m-for-first-time-a3892461.html.

Randell-Moon, H. (2016) 'Body, Crown, Territory: Geocorpographies of the British Monarchy and White Settler Sovereignty.' In Security, Race, Biopower. London: Palgrave, pp.41-59.

Rayner, G. (2013) 'Former BBC PR boss Sally Osman becomes Prince of Wales's new communications chief.' The Telegraph. 18th April. [Accessed 26/08/2016] http://www.telegraph.co.uk/news/uknews/prince-charles/10003570/FormerBBC-PR-boss-Sally-Osman-becomes-Prince-of-Waless-new-communicationschief.html.

Rayner, G. (2014) 'An American at the Palace: Duke and Duchess of Cambridge hire RBS spin doctor Jason Knauf.' Telegraph, 21st November. [Accessed 16/06/2015] http://www.telegraph.co.uk/news/uknews/katemiddleton/11245163/An-American-at-the-Palace-Duke-and-Duchess-ofCambridge-hire-RBS-spin-doctor-Jason-Knauf.html.

Republic (2015) Royal Expenses: Counting the Cost of the Monarchy.

Republic (2016) How to win the argument. London.

Riley-Smith, B. (2016) 'Queen facing million-pound black hole in estate finances after Brexit.' The Telegraph. 22nd October. [Accessed 31/10/2016] 
http://www.telegraph.co.uk/news/2016/10/22/queen-facing-million-poundblack-hole-in-estate-finances-after-b/.

Ritchie, J. and Markwell, D. (2006) 'Australian and Commonwealth republicanism.' The Round Table, 95(387) pp. 727-737.

Robins, N. (2012) The Corporation That Changed the World: How the East India Company Shaped the Modern Multinational. Second, London: Pluto Press.

Salandy, T. (2018) The British Royal Wedding, Empire and Colonialism. CounterPunch. [Accessed 08/01/2020] https://www.counterpunch.org/2018/05/23/the-british-royal-weddingempire-and-colonialism/.

Sassen, S. (2001) The Global City: New York, London, Tokyo. New Jersey: Princeton University Press.

Savage, M. (2015) Social Class in the 21st Century. London: Pelican.

Savage, M. and Williams, K. (2008) Remembering elites. Oxford: Blackwell Publishing.

Sawer, P. (2016) “'Prince Andrew brokered $£ 385 m$ deal with Kazakh regime while working as British trade envoy."' The Telegraph. 20th May. [Accessed 11/07/2018] https://www.telegraph.co.uk/news/2016/05/20/duke-brokered$385 \mathrm{~m}$-for-corrupt-regime-while-working-as-british-t/.

Sayer, A. (2015) Why We Can't Afford the Rich. London: Policy Press.

Shakespeare, S. (2015) Queen to pay the Living Wage to servants. Daily Mail [Accessed on 22/08/2016] http://www.dailymail.co.uk/news/article3085742/SEBASTIAN-SHAKESPEARE-Queen-pay-Living-Wage-servants.html.

Sherman, H. D. and Young, S. D. (2016) 'Where Financial Reporting Still Falls Short.' Harvard Business Review.

Shrimsley, R. (2011) 'Royals to royalties: the Firm is in business.' Financial Times. 30th June. [Accessed 16/08/2016] http://www.ft.com/cms/s/0/e31c28aca341-11e0-8d6d-00144feabdc0.html\#axzz4HU4im7FV.

Shrubsole, G. (2019) Who Owns England? London: William Collins.

Skeggs, B. (2019) 'The forces that shape us: The entangled vine of gender, race and class.' The Sociological Review, 67(1) pp.28-35.

Smith, D. R. (2016) Elites, Race and Nationhood: The Branded Gentry. London: Palgrave.

Somerset, A. (1984) Ladies in Waiting: From the Tudors to the Present Day. London: Phoenix Press. 
Stockman, C. (2014) 'The Royal Household.' Royal Central. 28th October. [Accessed 06/10/2016] http://royalcentral.co.uk/blogs/the-royal-household38785.

Sunkin, M. and Payne, S. (eds) (1999) The Nature of the Crown: A Legal and Political Analysis. New York, USA: Oxford University Press.

Telegraph Reporters (2016) 'Prince Andrew facing more questions about Kazakhstan links.' The Telegraph. 23rd May. [Accessed 11/07/2018] https://www.telegraph.co.uk/news/2016/05/22/prince-andrew-facing-morequestions-about-kazakhstan-links/.

The Commonwealth (2013) Charter of the Commonwealth.

The Crown Estate (2016a) Another record income return of E304.1 million to the public finances. The Crown Estate. [Accessed on 04/11/2016] http://www.thecrownestate.co.uk/news-and-media/news/2016/anotherrecord-income-return-of-304-1m-to-the-public-finances/.

The Crown Estate (2016b) Our people. The Crown Estate. [Accessed 04/11/2016] http://www.thecrownestate.co.uk/who-we-are/our-people/.

The Crown Estate (2018) The Crown Estate announces E329.4m income returned for the public finances. The Crown Estate. [Accessed 03/07/2019] https://www.thecrownestate.co.uk/en-gb/media-and-insights/news/2018-thecrown-estate-announces-3294m-income-returned-for-the-public-finances/.

The Equality Trust (2017) The Equality Trust Wealth Tracker 2017.

The Peerage (2015) William James Robert Peel, 3rd Earl Peel. The Peerage. [Accessed 24/10/2016] http://www.thepeerage.com/p10629.htm\#i106285.

The Royal Household (2015) Job Vacancies: Housekeeping Assistant. The Royal Household. [Accessed 12/10/2016]

https://theroyalhousehold.tal.net/vx/mobile-0/appcentre-1/brand0/candidate/so/pm/1/pl/4/opp/844-Housekeeping-Assistant/en-GB.

The Royal Household of Queen Elizabeth II (2018) The Sovereign Grant and Sovereign Grant Reserve, Annual Report and Accounts, 2017-18. London.

The Royal Household of Queen Elizabeth II (2019) 'The Soverign Grant and Sovereign Grant Reserve Annua Report and Accounts 2018-19.' House of Commons Research Paper.

The Royal Post (2013) 'What's The Deal with Ladies-in-Waiting?' The Royal Post. 12th November. [Accessed on 11/08/2016] http://theroyalpost.com/2013/11/12/whats-the-deal-with-ladies-in-waiting/.

The Telegraph (2011) 'Sir Michael Peat to step down as advisor to Prince of Wales.' The Telegraph. 24th January. [Accessed 12/10/2016] 
http://www.telegraph.co.uk/news/uknews/theroyalfamily/8278436/SirMichael-Peat-to-step-down-as-advisor-to-Prince-of-Wales.html.

Tichelar, M. (2018) The Failure of Land Reform in Twentieth Century England: The Triumph of Private Property. London: Routledge.

Verkaik, R. (2010a) Queen tried to use state poverty fund to heat Buckingham Palace. The Independent. [Accessed on 09/09/2015] http://www.independent.co.uk/news/uk/home-news/queen-tried-to-use-statepoverty-fund-to-heat-buckingham-palace-2088179.html.

Verkaik, R. (2010b) Queen's finances: crisis facing the monarch revealed in secret documents. Belfast Telegraph. [Accessed on 07/10/2016] http://www.belfasttelegraph.co.uk/news/queens-finances-crisis-facing-themonarch-revealed-in-secret-documents-28527628.html.

Virdee, S. and McGeever, B. (2017) 'Racism, Crisis, Brexit.' Ethnic and Racial Studies, Online first.

Volcic, Z. and Andrejevic, M. (eds) (2016) Commercial Nationalism: Selling the Nation and and Nationalizing the Sell. London: Palgrave.

Watt, N. (2014) 'How a hung parliament would put the Queen centre stage.' The Guardian. 14th February. [Accessed 12/10/2016] https://www.theguardian.com/uk/2010/feb/14/queen-power-hungparliament.

Williams, E. (1964) Capitalism and Slavery. London: Andre Deutsch Limited.

Yelin, H and L Clancy (forthcoming). 'Doing impact work while female: hate tweets, 'hot potatoes' and having 'enough of experts'. European Journal of Women's Studies

\footnotetext{
${ }^{1}$ George VI's 'the Family Firm' softens and distracts from institutional operations using notions of familial intimacy and the Victorian association between family businesses and morality. See Clancy, forthcoming.

2 Since writing this article, the official royal website has removed salary information from many of the job advertisements. ${ }^{3}$ Bates (2015) estimates this to be approximately 7,000 paintings, 40,000 watercolours and 150,000 prints (from artists such as Rembrandt and da Vinci), plus eighteenth century French furniture, statues, and tapestries.

${ }^{4}$ These calculations are usually based on the annual finance reports, which as described are often inaccurate
} 